\title{
(ASINAN GULE) ANAK SIAGA BENCANA GUNUNG MELETUS MELALUI METODE PERMAINAN TRADISIONAL
}

\author{
N.K.Sutiasih ${ }^{1}$, N.N.Binarht ${ }^{2}$, N.P. R.Pradnyadewi ${ }^{3}$, D.M.P.Gayatri ${ }^{4}$
}

\begin{abstract}
ABSTRAK
Akibat bencana gunung meletus orang tua siswa khawatir meninggalkan anak-anak di sekolah dasar karena belum tahu tentang bencana gunung meletus. Anak-anak sekolah dasar kesulitan memahami materi kebencanaan hanya dengan sosialisasi. Pemecahan masalah yang dapat diberikan adalah adanya kegiatan "Anak Siaga Bencana Gunung Meletus melalui metode permainan tradisional". Permainan tradisional dilakukan untuk memudahkan penyampaian materi tentang gunung meletus, serta dapat melestarikan budaya permainan tradisional. Program ini dilakukan untuk menyadarkan anak-anak terhadap ancaman gunung meletus,cara penanggulangan, dan menerapkan metode penanggulangan bencana ketika terjadi bencana.Kegiatan dilangsungkan di Sekolah Dasar Negeri 2 Bhuana Giri selama 4 bulan. Metode pelaksanaan yaitu tahap penyusunan kegiatan, persiapan, pelaksanaan kegiatan, dan evaluasi kegiatan. Berdasarkan hasil pre-test dan post-test dapat dilihat bahwa terjadi peningkatan pengetahuan yang cukup signifikan. Setelah dilaksanakannya kegiatan ini, 77\% siswa memiliki pengetahuan sangat baik. Sedangkan sebelum dilaksanakan program pengetahuan siswa hanya mencapai kategori baik sebesar $26,67 \%$.
\end{abstract}

Kata Kunci: Gunung Meletus, anak siaga bencana, Permainan Tradisional

\begin{abstract}
As a result of the erupting mountain disaster, parents of students were worried about leaving their children in elementary school because they didn't know about the mitigation of the volcanic eruption. Elementary school children find it difficult to understand information about disasters only through dissemination. The solution to the problem that can be proposed is the activity of "Children Alert of erupting mountain disasters" through traditional game methods.Traditional games are performed to facilitate the delivery of information about volcanic eruptions in addition to being able to preserve traditional games. This program was carried out to make children aware of the threat of volcanic eruptions, mitigation methods, and apply disaster management methods when a disaster occurs. The activity was held at 2 Bhuana Giri Public Elementary School for 4 months. The method of implementation was the stage of preparation of activities, preparation, implementation of activities, and evaluation of activities. Based on the results of the pre-test and post-test, it can be seen that there is a significant increase in knowledge. After the implementation of this activity, $77 \%$ of students have very good knowledge. Whereas before being implemented the student knowledge program only reached a good category of $26.67 \%$.
\end{abstract}

\section{PENDAHULUAN}

\subsection{Latar Belakang}

Negara Indonesia sebagai negara kepulauan yang termasuk dalam jalur yang dilalui cincin api

\footnotetext{
${ }^{1}$ Mahasiswa Program Studi Agribisnis, Fakultas Pertanian, Universitas Udayana, kadeksutiasih5@gmail.com

${ }^{2}$ Mahasiswa Program Studi Agroekoteknologi, Fakultas Pertanian, Universitas Udayana, nofiannafi@gmail.com

${ }^{3}$ Mahasiswa Program Studi Agribisnis, Fakultas Pertanian, Universitas Udayana, ratihpradnyaadw@gmail.com

${ }^{4}$ Mahasiswa Program Studi Agribisnis, Fakultas Pertanian, Universitas Udayana, pradnyadesak21@gmail.com
} 
menyebabkan Indonesia banyak mengalami bencana gunung meletus. Bali yang merupakan pulau seribu pura juga mengalami bencana gunung meletus. Bencana gunung meletus terjadi di Kabupaten Karangasem sejak pertengahan Agustus 2017. Bencana ini ditandai dengan adanya beberapa gempa vulkanik. Gempa yang terjadi sempat menghilang dan muncul kembali pada awal September 2017. Aktivitas Gunung Agung yang terus meningkat menyebabkan status Gunung Agung ditingkatkan dari level Normal ke level Waspada, dan kemudian menjadi level Siaga dan awas. Karangasem mengalami 844 gempa vulkanik tanggal 25 September 2017 dan 300-400 gempa bumi tanggal 26 September 2017. Pada akhir Oktober 2017, status diturunkan dari Awas menjadi Siaga. Sejak akhir tahun 2017 hingga Juli 2018, terjadi beberapa kali letusan freatik, erupsi magmatik, semburan abu vulkanik, dan hujan abu. Lebih dari 29.000 pengungsi sementara dilaporkan tinggal di lebih dari 270 akibat kejadian ini. Pada akhir tahun 2018 sampai pertengahan tahun 2019 banyak terjadi letusan dan gempa di sekitar gunung agung. Letusan terus berlajut hingga tahun 2019. Letusan terus terjadi pada bulan Maret 2019 disertai dengan hujan abu dan lahar dingin. Letusan juga terjadi pada bulan April dan Mei 2019. Pada bulan Juni letusan terjadi pada tanggal 10 dan 13 Juni 2019.

Desa Bhuana Giri, Kecamatan Bebandem berada di KRB III dan radius 6 kilometer dari Gunung Agung. Masyarakat merasa resah dan takut bila terjadi letusan secara tiba-tiba. Keresahan masyarakat ini disebabkan karena ketidaktahuan masyarakat mengenai bencana yang mereka alami. Ketika anak-anak mereka kembali bersekolah, orang tua merasa resah meninggalkan anak mereka di sekolah. Orang tua siswa merasa perlu apabila dilakukan kegiatan Siaga Bencana Gunung Meletus. Anak-anak yang panik ketika bencana, membuat guru-guru mengharapkan diadakan pemberian materi dan simulasi bencana gunung meletus. Hal ini dikarenakan Anak-anak Sekolah Dasar yang belum tahu tentang bencana alam gunung meletus membuat resah dan takut dalam menempuh pendidikan.

Salah satu sekolah yang terdampak bencana gunung meletus adalah SD Negeri 2 Bhuana Giri. Keadaan ini juga membuat banyak pekerjaan masyarakat yang terhenti akibat aktivitas gunung api Agung. Namun anak-anak sekolah dasar masih kesusahan memahami materi kebencanaan. Anak-anak tidak akan paham dengan mudah jika hanya menggunakan materi sosialisasi seperti biasanya. Sehingga perlu adanya solusi pemberian materi kebencanaan dengan teknik yang menyenangkan dan mudah dipahami anak-anak. Dari masalah diatas maka salah satu pemecahan masalah yang dapat diberikan adalah adanya kegiatan "Anak Siaga Bencana Gunung Meletus (ASINAN GULE) Melalui Metode Permainan Tradisional”. Dengan adanya kegiatan ini anak-anak Sekolah Dasar akan mengetahui mengetahui cara menghadap bencana gunung meletus dan bisa mencegah korban jiwa. Teknik permainan secara tradisional juga dilakukan untuk melestarikan budaya permainan tradisional yang sudah mulai dilupakan karena perkembangan teknologi. Selain itu melalui permainan tradisional maka anak-anak akan lebih bersemangat dan memahami dengan cepat materi siaga bencana gunung meletus.

\subsection{Rumusan Masalah}

1. Bagaimana cara menyadarkan anak-anak terhadap ancaman bencana alam?

2. Bagaimana cara mengajarkan penanggulangan bencana gunung meletus?

3. Bagaimana cara menerapkan penanggulangan bencana ketika terjadi bencana?

\subsection{Tujuan}

1. Untuk mengetahui cara menyadarkan anak-anak terhadap ancaman bencana alam.

2. Untuk mengetahui cara mengajarkan penanggulangan bencana gunung meletus.

3. Untuk mengetahui cara menerapkan penanggulangan bencana ketika terjadi bencana.

\section{METODE}


Pelaksanaan kegiatan PKM-M ini dilaksanakan di Sekolah Dasar Negeri 2 Bhuana Giri selama empat bulan yaitu pada bulan Maret-Juni. Rangkaian program yang dilaksanakan adalah sebagai berikut

\subsection{Penyusunan Kegiatan}

Tahap awal dilakukannya kegiatan adalah penyusunan kegiatan. Konsep kegiatan yang direncanakan sebagai berikut: metode pelaksanaan program siaga bencana gunung meletus kepada anak sekolah dasar yang akan dilaksanakan di Desa Bhuana Giri, Kecamatan Bebandem, Kabupaten Karangasem, Provinsi Bali. Anak SD Negeri 2 Bhuana Giri diberi sosialisasi, edukasi dengan permainan tradisional, pelatihan dan simulasi tentang siaga bencana gunung meletus. Selain itu disusun konsep permainan tradisional yang akan dilakukan untuk menarik perhatian peserta.

\subsection{Persiapan}

Pada tahap ini dilakukan persiapan sarana dan prasana yang diperlukan dalam menjalankan program ini. Persiapan dilakukan baik untuk sosialisasi, tahap pelaksanaan dan evaluasi program. Persiapan materimateri yang digunakan sebagai bahan sosialisasi dalam bentuk modul dan juga pembuatan power point. Pembelian segala perlengkapan yang diperlukan dan pembuatan alat permainan tradisional.

\subsection{Pelaksanaan Kegiatan}

Kegiatan ini dilakukan setelah segala persiapan dan peralatan yang dibutuhkan telah lengkap. Teknis pelaksanaan kegiatan ini akan dilakukan dengan tujuh kali kegiatan yaitu:

1. Kunjungan Awal

Pada kegiatan sebelum pelaksanaan program akan diawali dengan kujungan dan mengecek keadaan anak-anak sekolah dasar. Pada kegiatan ini membahas kegiatan lebih lanjut dengan kepala sekolah dan guru-guru SD Negeri 2 Bhuana Giri untuk mengetahui kebutuhan sekolah dan keadaan anak-anak SD.

2. Wawancara

Pada sebelum pelaksanaan program akan dilakukan wawancara dengan anak-anak sekolah dasar dan peninjauan kembali keadaaan anak-anak SD Negeri 2 Bhuana Giri. Selain itu dilakukan wawancara dengan orang tua siswa. Tujuan wawancara adalah untuk mengetahui keadaan dan kebutuhan sasaran.

3. Pendekatan dan Analisis Keadaan

Pada pertemuan hari pertama akan diawali dengan melakukan sosialisasi pentingnya kesiapsiagaan menghadapi bencana gunung meletus. Pada kegiatan ini dilakukan analisis pengetahuan siswa mengenai bencana gunung meletus sebelum pelaksanaan program. Kegiatan sosialisasi dilakukan di luar kelas.

4. Perkenalan Permainan dan Sosialisasi

Pada pertemuan hari kedua diadakan pengenalan dan percobaan permainan tradisional yang akan digunakan dalam program yang bertujuan untuk membuat anak-anak dapat memahami materi dengan baik. Selain itu dilakukan perkenalan dan penjelasan kepada anak-anak Sekolah Dasar mengenai gambaran umum bencana gunung meletus. Pengenalan yang diberikan meliputi pengertian, fungsi gunung, ciri-ciri serta penyebab gunung meletus, serta jenis gunung api. Pada

\section{4 | BULETIN UDAYANA MENGABDI}


pertemuan kedua juga diperkenalkan mengenai lagu "Tanda Gunung Meletus" . Penyampaian materi dilakukan di dalam kelas sedangkan permainan tradisional dilakukan di luar kelas.

5. Permainan Kotak Pos dan Sosialisasi

Pada pertemuan hari ketiga akan dijelaskan mengenai kondisi ketika terjadinya bencana gunung meletus, cara penyelamatan diri (sebelum bencana, saat terjadi bencana dan setelah terjadi bencana), dan dampak gunung meletus. Penjelasan penyelamatan ketika terjadinya bencana juga dilakukan melalui permainan kotak pos. Cara perkenalan dilakukan dengan melakukan peragaan gerakan tubuh dari salah satu siswa dan ditebak oleh siswa lainnya mengenai cara penyelamatan diri. Kegiatan ini dilakukan di dalam kelas.

6. Edukasi dengan Permainan Engkek dan Bakiak

Pada pertemuan hari keempat akan dilakukan dengan mengedukasi materi sebelumnya melalui permainan engklek dan bakiak/terompah. Materi-materi yang digunakan dalam permaianan engklek adalah pengertian, tipe gunung api, fungsi dan penyebab gunung meletus. Sedangkan permainan bakiak dilakukan dengan materi keadaan saat gunung meletus dan bencananya, serta dampak yang diakibatkan bencana gunung meletus. Kegiatan ini dilakukan di luar kelas dan di dalam kelas berupa review materi sebelumnya.

7. Simulasi Kebencanaan

Pada pertemuan hari kelima sekaligus pertemuan terakhir akan diadakan simulasi mengenai bencana gunung meletus kepada anak-anak Sekolah Dasar. Pelaksanaan kegiatan simulasi dilakukan dua kali yaitu ketika gempa sebagai tanda gunung meletus dan ketika terjadinya bencana gunung meletus. Kegiatan ini dilakukan di luar dan dalam kelas.

\subsection{Evaluasi Kegiatan}

Dilakukan evaluasi terhadap keberlangsungan program dengan tanya jawab mengenai materi yang diberikan. Dilakukan penyebaran kuisioner untuk anak-anak Sekolah Dasar, untuk menguji tingkat pemahaman mereka terhadap bencana gunung meletus. Selain hal tersebut, keberhasilan program dapat juga dilihat melalui perubahan perilaku siswa ketika melakukan simulasi, apakah sudah dapat dilaksanakan dengan baik oleh siswa dan orang tua.

\section{HASIL DAN PEMBAHASAN}

\subsection{Hasil Kegiatan}

Untuk mengukur tingkat perubahan pengetahuan siswa maka dilakukan pre-test dan post-test kepada anak-anak sekolah dasar kelas 3 dan 4 dengan jumlah 30 anak. Berdasarkan hasil pre-test yang dilakukan sebelum pelaksanaan kegiatan, maka didapatkan data bahwa hanya 8 orang $(26,67 \%)$ siswa yang memiliki pengetahuan dengan kategori baik dan sangat baik. Dalam kategori cukup baik terdapat 11 orang $(36,67 \%)$ siswa. Sedangkan 11 orang anak $(36,67 \%)$ memiliki pengetahuan dengan kategori kurang baik. Sehingga dapat disimpulkan bahwa pengetahuan siswa SD kelas 3 dan 4 tentang bencana gunung meletus sebagian besar masih rendah.

Sedangkan berdasarkan hasil post-test yang dilakukan setelah kegiatan selesai dilaksanakan, didapatkan hasil bahwa ada peningkatan pengetahuan siswa mengenai bencana gunung meletus yaitu sebanyak 23 orang $(86,67 \%)$ memiliki pengetahuan dengan kategori sangat baik. Sebanyak 3 orang (10\%) memiliki pengetahuan dalam kategori baik, sebanyak 4 orang $(1,3 \%)$ dalam kategori cukup baik serta tidak ada anak yang memiliki pengetahuan dalam kategori kurang baik. Sehingga dapat dilihat bahwa terjadi 
peningkatan pengetahuan sebesar 60\%, dimana sebelum dilaksanakannya kegiatan tidak ada siswa yang memiliki pengetahuan dengan kategori sangat baik, hanya sebatas kategori baik pada sebagian kecil siswa dan sisanya berimbang pada kategori cukup baik dan kurang baik. Siswa yang hanya mengalami peningkatan pengetahuan yang sedikit bisa disebabkan banyak faktor seperti kemampuan individu, maupun keseriusan siswa dalam mengikuti program.

Perubahan keterampilan siswa dapat dilihat dari simulasi kebencanaan yang dilakukan. Simulasi bencana dilaksanakan pada pertemuan kelima dan dibagi menjadi 2 macam simulasi, yaitu simulasi bencana gempa bumi pra gunung meletus dan simulasi saat terjadinya letusan gunung. Pada video pertama yaitu simulasi gempa bumi, sebagian besar anak sudah mengetahui apa yang harus mereka lakukan ketika terjadi gempa bumi saat mereka sedang di dalam ruangan, yaitu mereka dapat bersembunyi di bawah kolong meja agar terhindar dari resiko terkena bangunan yang bisa saja runtuh akibat terjadi gempa. Kemudian ketika gempa sudah berhenti, terlihat mereka segera keluar ruangan mengikuti petunjuk jalur evakuasi dengan tas yang diletakkan di atas kepala. Tindakan ini juga bertujuan untuk melindungi kepala dari reruntuhan bangunan yang mungkin saja terjadi pasca gempa. Namun anak-anak masih perlu diarahkan untuk meletakkan di atas kepala dan masih ada nak-anak yang tidak menaruh tas di kepala. Ketika sudah berada di ruang terbuka, mereka mengikuti arahan berkumpul dari guru atau dinas terkait untuk selanjutnya menunggu dijemput oleh orang tua mereka.

Kemudian pada simulasi kedua terlihat anak-anak keluar ruangan setelah mendengar suara simulasi letusan gunung, dan segera menuju titik kumpul yaitu di tengah lapangan dengan mengikuti jalur evakuasi setelah mendengar bunyi sirine. Anak SD menyiapkan masker dan kemudian menunggu dijemput orang tua mereka. Namun masih ada anak-anak yang panik dalam menghadapi bencana sekitar 3 orang siswa permpuan saat menghadapi simulasi gunung meletus. Siswa yang tidak memakai tas atau melindungi kepalanya saat keluar dari gempa sekitar 8 orang. Siswa tersebut masih perlu diingatkan untuk tas nya di taruh di atas kepala atau melalukan perlindungan kepala dari gempa. Ketika keluar ruangan adanya evakuasi maka ada 2 siswa yang belum tanggap dan cepat merespon evakuasi diri. Berdasarkan hasil post-test siswa yang memiliki tingkat pengetahuan sangat baik sebanyak 20 orang berada dalam kategori cepat dalam melakukan penyelamatan diri terhadap bencana gunung meletus, sedangkan 3 orang siswa dengan tingkat pengetahuan sangat baik berada dalam kategori sedang dalam menghadapi bencana gunung meletus. Sebanyak 2 orang siswa dengan tingkat pengetahuan baik berada dalam kategori cepat dalam melakukan penyelamatan diri, sedangkan sebanyak 1 orang siswa yang tingkat pengetahuannya baik berada dalam kategori sedang dalam menghadapi bencana. Sebanyak 1 orang siswa dari tingkat pengetahuan cukup baik berada pada kategori sedang dalam melakukan penyelamatan diri, sedangkan 3 orang siswa dari tingkat pengetahuan cukup baik berada dalam kategori lambat menyelamatkan diri dari bencana. Hal ini menunjukkan adanya hubungan yang berbanding lurus antara pengetahuan yang baik dengan keterampilan yang baik dan sigap. Masyarakat dapat menjadikan refrensi dalam membuat kegiatan siaga bencana gunung meletus maupun kegiatan kebencanaan lainnya.

\subsection{Kemanfaatan Pelaksanaan Program}

1. Kapanpun terjadi bencana gunung meletus maka anak-anak Sekolah Dasar akan siap menghadapinya karena sudah ada pengetahuan dan keterampilan menghadapi bencana gunung meletus sehingga proses evakuasi yang dilakukan akan lebih mudah.

2. Dengan mengetahui dampak dan bahaya yang dapat ditimbulkan oleh bencana gunung meletus maka korban jiwa dan kerugian harta benda dihindari.

3. Masyarakat akan mudah mengingat materi yang disampaikan dan juga dapat melestarikan permainan tradisional yang mulai dilupakan.

4. Kami melakukan monitoring dan evaluasi keberlanjutan program sebagai salah satu usaha menjembatani atau menghubungkan antara tim kami dengan siswa terlatih di SDN 2 Bhuana Giri. Kami melakukan kunjungan secara mendadak ke sekolah dasar dan membuat suatu situasi seolah-olah terjadi bencana gunung meletus dengan membunyikan sirine. Dalam situasi ini terdapat 5 orang $(16,67 \%)$ yang masih bingung dalam menyelamatkan diri. Sedangkan sebanyak

\section{6 | BULETIN UDAYANA MENGABDI}


25 orang (83\%) masih mengingat materi kebencanaan dan mampu menghadapi bencana. Tidak hanya siswa kelas 3 dan 4, tetapi siswa lainnya di SDN 2 Bhuana Giri juga mampu melakukan penyelamatan diri karena disebarkan oleh anak terlatih kepada teman-temannya.

5. Masyarakat dapat menjadikan referensi dalam membuat kegiatan siaga bencana gunung meletus maupun kegiatan kebencanaan lainnya.

\section{KESIMPULAN DAN SARAN}

\subsection{Kesimpulan}

1. Cara menyadarkan anak-anak terhadap ancaman bencana alam yang kami lakukan adalah membuat siswa tahu mengenai bencana gunung meletus dengan sosialisasi kebencanaan.

2. Cara mengajarkan penanggulangan bencana dilakukan dengan edukasi kebencanaan pada permainan tradisional bakiak, engklek, dan kotak pos sehingga siswa mau mempelajari penanggulangan bencana.

3. Cara menerapkan penanggulangan bencana dengan membuat siswa mampu melakukan penyelamatan diri melalui simulasi kebencanaan.

\subsection{Saran}

Diharapkan anak-anak yang sudah mendapatkan pelatihan dapat menyebarkan kepada anak-anak lainnya dan keluarganya.

\section{UCAPAN TRIMAKASIH}

Penulis mengucapkan banyak terimaksih kepada Direktorat Jenderal Pembelajaran dan Kemahasiswaan Kementrian Riset, Teknologi, dan Pendidikan Tinggi Republik Indonesia dan Universitas Udayana yang telah memberikan kesempatan dan memfasilitasi kami melakukan pengabdian masyarakat ini. Kami ucapkan terimakasih kepada SD Negeri 2 Bhuana Giri, Dosen Pendamping, Anak-anak SD N 2 Bhuana Giri, orang tua siswa dan teman-teman BEM FP Unud atas dukungan dan bantuannya.

\section{REFERENSI}

Azizah. 2018. Efektivitas Media Permainan Monopoli Materi Erupsi Gunung Berapi Terhadap Tingkat Pengetahuan Bencana pada Ekstrakurikuler Sekolah Siaga Bencana di SMP Negeri 1 Delanggu. Universitas Muhammadiyah Surakarta

Badan Nasional Penanggulangan Bencana. 2017. Tanggap Tangkas Tangguh Menghadapi Bencana. Jakarta: Pusat Data, Informasi dan Humas BNPB Direktorat Vulkanologi dan Mitigasi Bencana Geologi. 2006. Gunungapi

Januanesbi, Galan. 2014. Pembelajaran Vulkanologi Secara 3D Berbasis Augmented Reality. Universitas Muhammadiyah Surakarta

Mardia, A., dan Jafar, A. F. 2017. Efektifitas Penggunaan Media Pembelajaran Monopoly Game Smart Terhadap Minat Belajar Peserta Didik. Jurnal Pendidikan Fisika Vol. 5 No.1

Rahayu, dkk. 2014. Dampak Erupsi Gunung Merapi Terhadap Lahan dan Upaya-Upaya Pemulihannya. Jurnal Ilmu-Ilmu Pertanian Vol. XXIX No. 1 Maret 2014 